\title{
Cash Holdings and Finance Constraints in Indian Manufacturing Firms
}

\author{
Vikash Gautam $^{1, *}$, Ashish Singh ${ }^{2} \&$ Sarthak Gaurav ${ }^{3}$ \\ ${ }^{1}$ Chandragupt Institute of Management, Patna, India \\ ${ }^{2}$ SJM School of Management, Indian Institute of Technology, Mumbai, India \\ ${ }^{3}$ Asia Research Centre, London School of Economics, UK \\ *Corresponding author: Chandragupt Institute of Management, Patna, India. Tel: \\ 91-612-2230-305. E-mail: vikash.igidr@gmail.com
}

Received: May 13, $2014 \quad$ Accepted: June 24, 2014 Published: August 28, 2014

doi:10.5296/rae.v6i3.5621 URL: http://dx.doi.org/10.5296/rae.v6i3.5621

\begin{abstract}
This paper attempts to explore the effect of finance constraints by examining the propensity of firms to save cash out of cash flows. Drawing on cash-cash flow sensitivity (CCFS), we overcome the errors in attributing information in cash flows to real and financial components. We employ endogenous regime switching model for our empirical exercise. This model allows for multiple sorting variables, does not require finance constraints to increase monotonically with the sorting variables and enables firms to endogenously change regime over the sample period. Our findings suggest that firms portray significantly higher CCFS in the event of finance constraints.
\end{abstract}

Keywords: Finance constraints, Cash-cash flow sensitivity, Endogenous regime switching model 


\section{Introduction}

A recurrent difficulty in the corporate finance literature pertains to the identification of financially constrained firms. This is because finance constraints are not directly observable. Nonetheless, it is important to identify such firms as mere its existence questions a core assumption underlying the neoclassical theory, i.e., the existence of perfect capital markets. Finance constraints can arise for two primary reasons: adverse selection and moral hazard (or agency problem), both as a consequence of asymmetric information in the capital markets. The theories of adverse selection postulate that firms (as borrowers) face high cost of external finance because investors, who are unsure about their quality, seek a premium over and above the opportunity cost of funds they lend. This premium is to compensate for the expected loss associated with the funding of the high risk firms (Stiglitz and Weiss, 1981; Myers and Majluf, 1984). Moral hazard theories, on the other hand, assume that managers derive private benefits by operating on bigger firms; so they invest more whenever internal cash flows permit (Stulz, 1990). The owners, therefore, charge a premium to cover their cost of monitoring which is incurred to discipline the managers (Jensen and Meckling, 1976; Jensen, 1986). Since both the theories predict a premium on the external funds for a set of firms, investment by such firms is likely to be highly sensitive to the fluctuations in internal funds.

Investment-cash flow sensitivity (ICFS) is commonly used as the measure to indicate the presence of financially constrained firms where cash flows are taken as the measure of internal funds.(Note 1) In empirical investigations, the usual practice is to sort the sample of firms into groups based on the likelihood of being financially constrained using variables such as dividend payout, size, group affiliation, age, etc. The group having significantly higher cash flow sensitivity in the investment regression, after controlling for the growth opportunities is interpreted as financially constrained in comparison to the other group(s).(Note 2)

The use of ICFS, to indicate finance constraints in firms, however, is criticized on the ground that cash flows, besides capturing information on internal funds, also capture information on the growth opportunities of firms (Gilchrist and Himmelberg, 1995; Alti, 2003). Specifically, younger and smaller firms react more to an innovation in cash flows as it provides a greater revision of expected profitability. Therefore, one may wrongly infer some financially unconstrained firms to be financially constrained.

In order to address the aforementioned problem, Almeida, Campello and Weisbach (2004) suggest the use of 'cash-cash flow sensitivity (CCFS)' to indicate finance constraints in firms. The argument is based on the conjecture that when firms are financially constrained, there is a need to safeguard their profitable future investment needs. For this, they buffer cash as a liquidity management strategy. Since the ability of firms to save cash is contingent on their ability to generate cash flows, CCFS should be higher for the financially constrained firms. In contrast, financially unconstrained firms should not display a systematic propensity to save cash out of cash flows as the cost of external funds is negligible for them.(Note 3) The main advantage of this metric is that there is no need to decompose information contained in cash flows as the focus is on observed financial variables. 
Finance constraints literature also highlights three other issues. Firstly, using a single variable to sort firms into financially constrained and unconstrained group is problematic as there is a limitation on how much a single variable can explain (Hu and Schiantarelli, 1998; Hovakimian and Titman, 2006). Secondly, sorting firms into groups based on some variable(s) implies an assumption of monotonicity of finance constraints with the sorting variable(s). Such an assumption may not necessarily hold (Kaplan and Zingales, 1997; Hovakimian, 2009). Finally, the conditions leading to finance constraints may change with any positive or negative shock affecting a firm over time, where switching across regimes is likely to be endogenous to the firms' characteristics (Hu and Schiantarelli, 1998; Hovakimian and Titman, 2006).

In this paper, we attempt to investigate the presence of finance constraints in Indian manufacturing firms using CCFS, a la Almeida, Campello and Weisbach (2004). However, we use a different empirical strategy. We employ an endogenous regime switching model to analyse the determinants of cash holdings by firms. This method, besides estimating the cash holding function, also estimates a selection function. The selection function uses a set of factors to produce the likelihood of observations to be in either the constrained or the unconstrained regime. The endogenous regime switching model has the following advantages: firstly, it posits finance constraints as a multi-faceted phenomenon by capturing information from all the variables included in the selection equation. Secondly, it does not require finance constraints to increase monotonically with the variables used in the selection function. Finally, it allows firms to endogenously change regime over the sample period.

Indian manufacturing sector provides an interesting platform to study finance constraints faced by firms in the wake of the financial sector reforms initiated in 1991. Since the reforms the economy has been gradually opened up for freer trade and capital mobility creating a market driven environment. This has enabled firms to have greater flexibility with respect to their choice of capital structure. But, in spite of these reforms, the presence of finance constraints at the firm level is widely established in the Indian context.(Note 4) The characterisation of finance constraints in these studies, however, can be put to question as they use ICFS as the identification metric without addressing the criticism raised on the information contained in cash flows. A study using CCFS would give a comparative picture of finance constraints faced by firms in the Indian context. Our results suggest that firms portray significantly higher CCFS in the event of finance constraints.

The outline of the reminder of the paper is as follows. Section 2 reviews the literature on CCFS. Section 3 describes the data and variables. Section 4 presents the descriptive statistics and the results of the basic model. Section 5 describes the endogenous regime switching model and its estimation results. Section 6 presents the robustness analysis. Section 7 concludes. 


\section{Evidence on CCFS}

Almeida, Campello and Weisbach (2004), in suggesting the use of CCFS to indicate finance constraints faced by firms, use a two period model where the firm's objective is to maximize the expected lifetime sum of all dividends subject to budget and finance constraints. Their model predicts no systematic relationship between changes in cash holdings and current cash flows for unconstrained firms whereas positive relationship between changes in cash holdings and current cash flows for constrained firms. Empirically, they use five alternative schemes (dividend payout, asset size, bond ratings, commercial paper ratings, and the $\mathrm{KZ}$ index) to sort a sample of US manufacturing firms on the basis of their creditworthiness.(Note 5) They show that using each of the sorting schemes, CCFS is significantly greater for the constrained firms than the unconstrained firms.

Khurana, Pereira and Martin (2006) use panel data from 35 countries to evaluate the influence of financial development on firms' propensity to save cash out of their cash flows. They use an index of financial development for grouping the countries and find that cash-cash flow sensitivity is smaller in countries with greater financial development and vice-versa.(Note 6) Lin (2007) uses four alternative measures to sort the sample of publicly trading Taiwanese firms into unconstrained and constrained subsamples: age, ratio of bank debt to total debt, public debt issuance and correlation between real investment and dividend payout. The study finds that using each of the sorting schemes, the CCFS is significantly greater for the constrained firms. Ginglinger and Saddour (2007) examine the relation between cash holdings, quality of governance and financing constraints. The authors find that the governance quality has no impact on the cash holdings for the financially unconstrained firms but has a positive impact on the cash holdings of the financially constrained firms, particularly the family firms. Denis and Sibilkov (2010) examine why cash holdings are more valuable for the financially constrained firms than the unconstrained ones. Their results suggest that higher cash holdings allow constrained firms to undertake value-increasing projects which might otherwise be bypassed.

To the best of our knowledge, D'Espallier, Vandemaele and Peeters (2008) is the only study which attempts to evaluate the relative performance of ICFS and CCFS in identifying finance constraints faced by firms. They first estimate firm-specific ICFS and CCFS metric to avoid ex ante sample sorting criteria. In the second step they construct different sensitivity classes using a cluster analysis. Finally, they quantify the difference between the sensitivity-classes using a number of verification variables that vary with the degree of finance constraints. These verification variables include cash flow to capital ratio, sales growth, debt to capital ratio, interest coverage, dividends, cash to capital ratio and slack to capital ratio. Their results suggest that the ICFS is a better metric to indicate finance constraints faced by firms. However, they largely ignore the criticism relating to the use of ICFS, that is, errors in decomposing information contained in cash flows into real and financial parts, which motivated the identification of financing constraints based on CCFS. Therefore, one needs to be cautious while interpreting their results.

The studies reviewed above can be assessed based on the three points mentioned above- 
relying on a single variable to inform on finance constraints; implicit assumption of monotonicity of finance constraints with the sorting variable(s) and; restricting firms to be in a single regime throughout the sample period. Although the studies largely use multiple variables and allow firms to change regime, but they implicitly assume a monotonic relationship of finance constraints with the sorting variable(s). As discussed above, such an assumption is restrictive and warrants further elucidation.

Following an outline of the results in the CCFS literature, we discuss the data and the variables to be used for our analysis in the next section.

\section{Data and Variables}

This paper is based on major industries in the Indian manufacturing sector from 1993 to 2009. In fact, we use data from 1992, the year immediately after the structural reforms of 1991. But first year of data is lost in the course of analysis. We use PROWESS, corporate data directory of the Center for Monitoring of Indian Economy (CMIE) as the major data source. PROWESS is the largest and most comprehensive database of the financials on Indian firms covering around 3300 data items and ratios per firm. This database compiles information from multiple sources such as the Annual Report of firms, the Stock Exchanges, the Reserve Bank of India, the Securities and Exchange Board of India, the Depositories, etc. We also use the Reserve Bank of India (RBI) monthly bulletins to get data on the price deflators for constructing the replacement value of the capital stock (capital, henceforth).(Note 7) This transformation from levels to ratios makes it possible to compare variables over time and across firms. Moreover, such a transformation yields a trend-stationary series and controls for heterogeneity.

We choose firms based on the following criteria: Firstly, we consider only private domestic firms. Public and foreign firms are excluded because investments by such firms are directly controlled by the Ministry of Industry and a foreign parent company, respectively. They cannot be analysed in the framework of this study. Secondly, we select firms whose manufactured sales are at least 75 per cent of the total sales for at least two-third of the sample period. This ensures that the firms are mainly involved with manufacturing business and have not shifted to some other core activities, such as trading. Thirdly, we require firms to not to have an unreasonable jump in the manufactured sales.(Note 8) This excludes firms undergoing major restructuring from the analysis as it is beyond the scope of this paper. Fourthly, we exclude financially distressed firm-observations from the sample.(Note 9) Excluding distressed observations is important because a rupee from cash flows, at margin, is less likely to be retained as cash and more likely to be paid out to the creditors if a firm is in financial distress. Inclusion of distressed firms in the sample would thus bias the results against finding a relationship between cash holdings and cash flows. Fifthly, we require the firms to have at least four years of continuous data. This requirement is to facilitate our econometric specification and construction of variables. Finally, for variables which portray extreme values, we winsorise one percent observations at both the ends. Accounting for these conditions, we have a sample of 2350 firms with 24357 observations. 
In the analysis of CCFS, cash holding is defined as the sum of cash and marketable securities whereas cash flow is defined as the sum of retained profits and depreciation. The accelerator is used as a control to measure the growth opportunities of firms. Its use is criticized on the ground that it is a backward looking measure of the growth opportunities of firms. Tobin's $q$, on the other hand is forward looking measure. But, reliance on Tobin's q requires only listed firms in the sample. Since we have many unlisted firms in the sample, we do a separate exercise to accommodate for this concern. Among additional controls, sales/operating income is included as a measure of size because economies of scale are important in cash management for portfolio diversification. Capital expenditure is included because firms can run down their cash holdings to make such expenditure. Non-cash working capital is included as it can be a substitute for cash. Short term debt is also controlled for because firms may use it to build cash reserves.

Among the variables which are used in the selection function to sort the constrained firm-observations from the unconstrained ones, we use accelerator and Tobin's $q$ as proxies for growth opportunities. Firms with high growth opportunities indicate further scope for profitable investments. If such firms are well recognised by the market, it is less likely that they would face problems in raising funds. However, their inability to signal scope for profitable investments may cause a bottleneck in raising funds (Hovakimian and Titman, 2006). We use two stock measures of leverage- short term debt and long term debt and a flow measure namely, interest coverage to represent debt servicing by firms. More leveraged firms signal higher probability of default during a business downturn. Therefore, they may face higher hurdles in accessing the external capital (Jensen and Meckling, 1976). However, some leverage helps in avoiding the agency problem between the stock holders and the managers by disciplining the later (Lensink, Bo and Sterken, 2001). Firm size and maturity are two variables which are extensively used in the literature. Firms with greater size and maturity command more resources and get more analysts' coverage than the firms with smaller size and maturity, respectively. Hence, they are less likely to be constrained by external funds (Devereux and Schiantarelli, 1990). Along with size and age, asset tangibility also indicates firms' ability to obtain external capital. Higher asset tangibility allows firms to borrow more as it increases the value that can be captured by the creditors in the default state (Almeida and Campello, 2007). We also use dividend payout, export sensitivity, group affiliation and industry sales shock as additional controls. Firms facing hurdles in finding external finance are expected to choose low dividend payout (Fazzari, Hubbard, and Petersen, 1988). Firms which export more are more likely to be reputed and capable of surviving. Such firms are also less likely to be constrained (Ganesh-Kumar, Sen and Vaidya, 2001). Group firms have their internal capital market which acts as an additional source of funds (Hoshi, Kashyap, and Scharfstein, 1991). However, some business groups mainly exist to the benefit of the typically small number of investors that control a group leading to the expropriation of minority shareholders. So, the complicated ownership structures of business groups may lead to more severe agency conflicts (Bertrand, Mehta and Mullainathan, 2002). Firms in the industries with positive sales shock are more likely to have a better operating performance on account of the greater demand for their products. Such firms are less likely to have problems in accessing external finance (Kruse, 2002). 
In the following section, we present the descriptive statistics of the above discussed key variables along with the results of the basic model.

\section{Descriptive Statistics and Basic Model}

We present the descriptive statistics of the variables in Table 1. It is evident from the table that there is substantial heterogeneity in the characteristics of firms in the sample. It can be seen that the representative firm in the sample holds a significant amount of cash, which is around $30 \%$ of the capital stock.

Table 1. Descriptive statistics

\begin{tabular}{lccccc}
\hline Variables & Maximum & Mean & Median & Minimum & S. D. \\
\hline Cash $/ \mathrm{K}$ & 5.8120 & 0.2987 & 0.0724 & 0.0013 & 0.7812 \\
$\Delta$ Cash $/ \mathrm{K}$ & 1.6798 & -0.0002 & -0.0005 & -1.8213 & 0.3457 \\
Cash flows/K & 2.6802 & 0.2395 & 0.1393 & -0.1680 & 0.3818 \\
Accelerator/K & 11.7757 & 0.7004 & 0.2714 & -4.1386 & 1.9215 \\
Capexp/K & 46.9999 & 4.8401 & 2.5779 & 0.2106 & 6.9298 \\
Log sales & 7.6399 & 3.7341 & 3.7741 & -4.6052 & 1.6924 \\
$\Delta \mathrm{STD} / \mathrm{K}$ & 1.4854 & -0.0105 & 0.0000 & -1.6715 & 0.3605 \\
$\Delta \mathrm{NCWK} / \mathrm{K}$ & 4.2256 & -0.0428 & -0.0020 & -5.4486 & 1.0040 \\
\hline
\end{tabular}

Notes: The variables are defined in Appendix. The total number of observations is 24357 from 2350 firms.

The basic model to investigate the determinants of the change in cash holdings can be specified as:

$$
\begin{aligned}
& \Delta \operatorname{Cash}_{i, t}=f_{i}+\tau_{t}+\beta_{1}(\Delta \text { Cash })_{i, t-1}+\beta_{2}(\text { cash flows })_{i, t}+\beta_{3}(\text { accelerator })_{i, t} \\
& +\beta_{4}(\text { log sales })_{i, t}+\beta_{5}(\text { capexp })_{i, t}+\beta_{6}(\Delta N C W K)_{i, t}+\beta_{7}(\Delta S T D)_{i, t} \\
& +\varepsilon_{i, t} \quad \text { (1) }
\end{aligned}
$$

here, $\Delta$ Cash represents the change in cash holding of firm $i$ at time $t . f_{i}$ is firm-specific effect, $\tau_{t}$ is time-specific effect. Cash flows, accelerator, log sales, capexp (capital expenditure), $\triangle N C W K$ (change in non cash working capital) and $\triangle S T D$ (change in short term debt) are the regressors and; $\varepsilon_{i t}$ is white noise.(Note 10)

In line with our arguments, we expect the coefficient for cash flows to be positive due to the presence of constrained firms in the sample. Table 2 reports the OLS regression results for the specification in Equation (1). We find the coefficient for cash flows to be positive and significant, suggesting the presence of constrained firms in the sample.(Note 11) 


\section{Macrothink}

Table 2. The determinants of change in cash holdings

\begin{tabular}{lc}
\hline Dependent variable: $\Delta$ cash/K & Coefficients \\
\hline L. $\Delta$ slack/K & $-0.435^{* * *}$ \\
& $(65.04)$ \\
Cash flows/K & $0.286^{* * *}$ \\
& $(18.88)$ \\
Accelerator/K & $-0.009 * *$ \\
& $(4.17)$ \\
Capexp $/ \mathrm{K}$ & $0.024^{* * *}$ \\
& $(14.04)$ \\
Log sales & $-0.049^{*}$ \\
& $(2.16)$ \\
$\Delta \mathrm{STD} / \mathrm{K}$ & $0.077^{* * *}$ \\
& $(16.78)$ \\
$\mathrm{NCWK} / \mathrm{K}$ & $-0.029 * *$ \\
\hline Prob $>\mathrm{F}$ & $(15.32)$ \\
\hline
\end{tabular}

Notes: The estimation is done using OLS after controlling for firm and year effects. The variables are defined in the Appendix. The total number of observations is 17220 . ***, ** and $*$ denote level of significance at $0.1 \%, 1 \%$ and $5 \%$, respectively. Absolute t-statistics are in parentheses.

With the brief description of the basic model, we present the analysis of the cash holding behavior of firms using an endogenous regime switching model in the next section.

\section{CCFS using Endogenous Regime Switching Model}

\subsection{The Model}

In any given year a firm may operate in either of the two regimes, financially constrained or unconstrained. Since the points of regime change are not observable, we use an endogenous regime switching model.(Note 12) This model endogenously determines the likelihood of a firm to be financially constrained in any year using multiple firm characteristics. The model is composed of the following system of simultaneous equations:

$$
\begin{gathered}
\Delta \operatorname{Cash}_{1 i t}=X_{i t} \beta_{1}+u_{1 i t} \\
\Delta \operatorname{Cash}_{2 i t}=X_{i t} \beta_{2}+u_{2 i t} \\
y_{i t}^{*}=Z_{i t} \gamma+\varepsilon_{i t}
\end{gathered}
$$

Equations (2) and (3) are the structural equations that describe the cash holding behavior of firms in the alternative regimes. Equation (4) is the selection equation that determines firms' propensity to be in one or the other regime. $X_{i t}$ is the set of determinants of cash holding behavior; $y_{i t}^{*}$ is a latent variable measuring the likelihood of firm $i$ to be in either of the regimes at time $t ; Z_{i t}$ is the set of the determinants of $y_{i t}^{*} ; \beta_{1}, \beta_{2}$, and $\gamma$ are the parameters; 
and $u_{1 i t}, u_{2 i t}$ and $\varepsilon_{i t}$ are the residuals. We assume that $u_{1 i t}, u_{2 i t}$, and $\varepsilon_{i t}$ are jointly normally distributed with mean vector 0 and covariance matrix $\Sigma=\left[\begin{array}{ccc}\sigma_{11} & \sigma_{12} & \sigma_{1 \varepsilon} \\ \sigma_{12} & \sigma_{22} & \sigma_{2 \varepsilon} \\ \sigma_{1 \varepsilon} & \sigma_{2 \varepsilon} & 1\end{array}\right]$. This assumption permits a nonzero correlation between the shocks to cash holding behavior and the shocks to firm's characteristics. Variance of $\varepsilon_{i t}\left(\sigma_{\varepsilon \varepsilon}\right)$ is normalised to unity as we can estimate only $\gamma / \sigma_{\varepsilon}$, but not $\gamma$ and $\sigma_{\varepsilon}$ separately.

The observed change in cash holding, $\Delta \operatorname{Cash}_{i t}$, is defined as:

$$
\begin{aligned}
& \Delta \operatorname{Cash}_{i t}=\Delta \operatorname{Cash}_{1 i t} \quad \text { if } \quad y_{i t}^{*}<0 \\
& \Delta \operatorname{Cash}_{i t}=\Delta \operatorname{Cash}_{2 i t} \quad \text { if } \quad y_{i t}^{*} \geq 0
\end{aligned}
$$

Although we cannot observe a firm being in one regime or the other, we can calculate the probability with which each one of them occurs:

$$
\begin{gathered}
\operatorname{Prob}\left(\Delta \operatorname{Cash}_{1 i t}\right)=\operatorname{Prob}\left(Z_{i t} \gamma+\varepsilon_{i t}<0\right)=\operatorname{Prob}\left(\varepsilon_{i t}<-Z_{i t} \gamma\right)=\Phi\left(-Z_{i t} \gamma\right) \\
\operatorname{Prob}\left(\Delta \operatorname{Cash}_{1 i t}\right)=\operatorname{Prob}\left(Z_{i t} \gamma+\varepsilon_{i t} \geq 0\right)=\operatorname{Prob}\left(\varepsilon_{i t} \geq-Z_{i t} \gamma\right)=1-\Phi\left(-Z_{i t} \gamma\right)
\end{gathered}
$$

here $\Phi($.$) is the cumulative distribution function. \Delta \operatorname{Cash}_{i t}$ is, thus, a weighted conditional density function of $u_{1 i t}$ and $u_{2 i t}$ with weights $\Phi\left(-Z_{i t} \gamma\right)$ and $\left[1-\Phi\left(-Z_{i t} \gamma\right)\right.$, respectively.

$$
\begin{aligned}
& \Delta \operatorname{Cash}_{i t}=\phi\left(u_{1 i t} \mid \varepsilon_{i t}<-Z \gamma\right) \Phi\left(-Z_{i t} \gamma\right)+\phi\left(u_{2 i t} \mid \varepsilon_{i t} \geq-Z \gamma\right)\left[1-\Phi\left(-Z_{i t} \gamma\right)\right] \\
& =\phi\left(u_{1 i t}, \sigma_{11}\right) \Phi\left[\frac{-Z_{i t} \gamma-\frac{\sigma_{1 \varepsilon}}{\sigma_{11}} u_{1 i t}}{\sqrt{1-\frac{\sigma_{1 \varepsilon}^{2}}{\sigma_{11}}}}\right]+\phi\left(u_{2 i t}, \sigma_{22}\right)\left[1-\Phi\left(\frac{-Z_{i t} \gamma-\frac{\sigma_{2 \varepsilon}}{\sigma_{22}} u_{2 i t}}{\sqrt{1-\frac{\sigma_{2 \varepsilon}^{2}}{\sigma_{22}}}}\right)\right]
\end{aligned}
$$

where $\phi($.$) denotes the normal density function; \phi\left(u_{j i t} \mid.\right)$ denotes conditional density function and $\phi\left(u_{j i t}, \sigma_{j j}\right)$ denotes the marginal density function for $j=\{1,2\}$.(Note 13) For the panel of $N$ firms with $T_{i}$ observations for firm $i$, the log likelihood function is given by

$$
L=\sum_{i=1}^{N} \sum_{t=1}^{T_{i}} \log \left(\operatorname{Cash}_{i t}\right)
$$

$\beta_{1}, \beta_{2}$ and $\gamma / \sigma$ can be estimated by maximising the log-likelihood function.

\subsection{Results of the Endogenous Regime Switching Model}

Empirical specification for the equations (2) and (3) describing the cash holding behavior of firms is same as the one used in equation (1). The variables used for estimating equation (4) describing the selection equation are- log sales, log age, dividend payout, cash holdings, asset tangibility, accelerator, short term debt, long term debt, export sensitivity and industry sales 
shock.

Table 3 reports the estimation results from the endogenous regime switching model. Panel A presents the estimates of the selection equation whereas Panel B documents the same for the cash holdings equation. We rely on $\chi 2$ test as suggested by Goldfeld and Quandt (1976) to validate the existence of two distinct cash holding regimes. The test rejects the hypothesis of similar cash holding behavior of firms in the two regimes at $0.1 \%$ significance level. We first look at the coefficients of cash flows (Panel B) to identify the constrained regime. It is significantly greater in the second regime. Therefore, following our hypothesis, we consider the second regime as financially constrained and the first as financially unconstrained.

Table 3. Endogenous regime switching regression

Panel A. The selection equation

\begin{tabular}{lc}
\hline & Coefficients \\
\hline Log sales & $0.0785^{* * *}$ \\
Log age & $(21.66)$ \\
& $-0.0346^{* *}$ \\
Dividend payout/K & $(3.13)$ \\
Cash holding/K & -0.0135 \\
& $(0.81)$ \\
Asset tangibility/K & $-0.0321^{* * *}$ \\
& $(17.78)$ \\
Accelerator/K & $-0.0077^{* * *}$ \\
Short term debt/K & $(5.03)$ \\
Long term debt/K & $-0.0006^{*}$ \\
Export sensitivity & $(2.04)$ \\
Group affiliation & -0.0022 \\
Industry sale shock & $(1.69)$ \\
& $0.0057^{* * *}$ \\
Prob> F & $(5.03)$ \\
\hline
\end{tabular}


Panel B. The cash holdings equation

\begin{tabular}{lccc}
\hline Dependent variable: & $\begin{array}{c}\text { Regime } 1 \\
\text { coefficients }\end{array}$ & $\begin{array}{c}\text { Regime } 2 \\
\text { coefficients }\end{array}$ & $\begin{array}{c}\text { p-value for difference } \\
\text { in coefficients }\end{array}$ \\
\hline Lcash/K $\Delta$ cash holdings/K & $-0.0031^{*}$ & $-0.4996^{* * *}$ & 0.0000 \\
& $(2.41)$ & $(19.42)$ & \\
Cash flows/K & $0.0218^{* * *}$ & $0.3249^{* * *}$ & 0.0000 \\
& $(8.21)$ & $(5.46)$ & \\
Accelerator/K & $-0.0009^{*}$ & -0.0117 & 0.1958 \\
& $(2.34)$ & $(1.40)$ & \\
Capital expenditure/K & $-0.0017^{* * *}$ & $-0.0296^{* * *}$ & 0.0000 \\
& $(5.66)$ & $(4.56)$ & \\
Log sales & 0.0023 & -0.1140 & 0.1543 \\
& $(1.79)$ & $(1.40)$ & 0.0000 \\
$\Delta \mathrm{STD} / \mathrm{K}$ & $0.0042^{* * *}$ & $0.0817^{* * *}$ & $(5.24)$ \\
& $(4.10)$ & $-0.0333^{* * *}$ & 0.0000 \\
$\Delta \mathrm{NCWK} / \mathrm{K}$ & $0.0060^{* * *}$ & $(4.72)$ & \\
\hline Prob $>\mathrm{F}$ & $(12.65)$ & 0.000 & \\
\hline
\end{tabular}

Notes: The variables are defined in the Appendix. The total number of observations is 17220 . The estimation is done after controlling for firm and year effects. $* * *, * *$ and $*$ denote level of significance at $0.1 \%, 1 \%$ and $5 \%$, respectively. Absolute t-statistics are in parentheses.

The estimates of the selection equation (Panel A) reveal that all the selection characteristics, except the dividend payout and the short term debt, significantly determine the likelihood of firms to be in a particular regime. Specifically, firms with higher operating income, long term debt, export sensitivity; group affiliation and positive industry sales shock are more likely to be in the first (unconstrained) regime. Also, firms with lower maturity, cash holding, asset tangibility and growth opportunities are more likely to be in the first regime.

In Panel B, the coefficients with the independent variables in both the regimes, except for the change in non cash working capital $(\triangle \mathrm{NCWK})$, show similar relationship with the change in cash holdings. The coefficient associated with lagged change in cash holdings is negative and significant suggesting that firms holding large amount of cash in the previous period are less likely to hold cash in the current period. The coefficient of capital expenditure is negative and significant which suggests that capital expenditure and cash holdings are competing uses of funds. Cash flow and change in short term debt $(\triangle \mathrm{STD})$ appear with significantly positive signs suggesting that they are important sources of cash holdings. Interestingly, cash holding is positively and significantly associated with change in non cash working capital ( $\triangle \mathrm{NCWK})$ in the first (unconstrained) regime whereas the sign turns negative in the second (constrained) regime. This suggests that when firms are unconstrained by external funds, they are likely to build NCWK and hold cash, simultaneously. Constrained firms, on the other hand, are more likely to run down NCWK to hold cash. We discuss the robustness of our estimates in the next section. 


\section{Robustness Checks}

To check the robustness of our estimates, we conduct two independent exercises. The first exercise pertains to a recursive depiction of the CCFS for the firm-observations in constrained and unconstrained groups. For this, we use the sample from the year 1993 to 2000 as the base and then add one year in subsequent steps to check the stability of the sensitivities. In the second exercise, we consider only listed firms, which allow us to compare our results with studies which have used Tobin's $q$ as a proxy for growth opportunities of firms.

\subsection{Stability of CCFS}

In Figure 1 we present the CCFS of the firm-observations where we use the sample from the year 1993 to 2000 as the base and then add one year in subsequent steps to check the stability of the sensitivities. It can be clearly seen that for the unconstrained group, the sensitivities remain close to zero throughout the considered samples (the maximum value being 0.0218 ) whereas for the constrained group it is much higher throughout the considered samples (the minimum value being 0.2125 ). This suggests that the cash holding behavior in the two regimes is significantly different across all the considered sub-samples. This confirms our main results. Moreover, for the constrained group it can also be seen that the sensitivities are higher (i.e., the extent of financing constraint is more) for the samples ending at the recent sub-prime crisis (2007 to 2009).

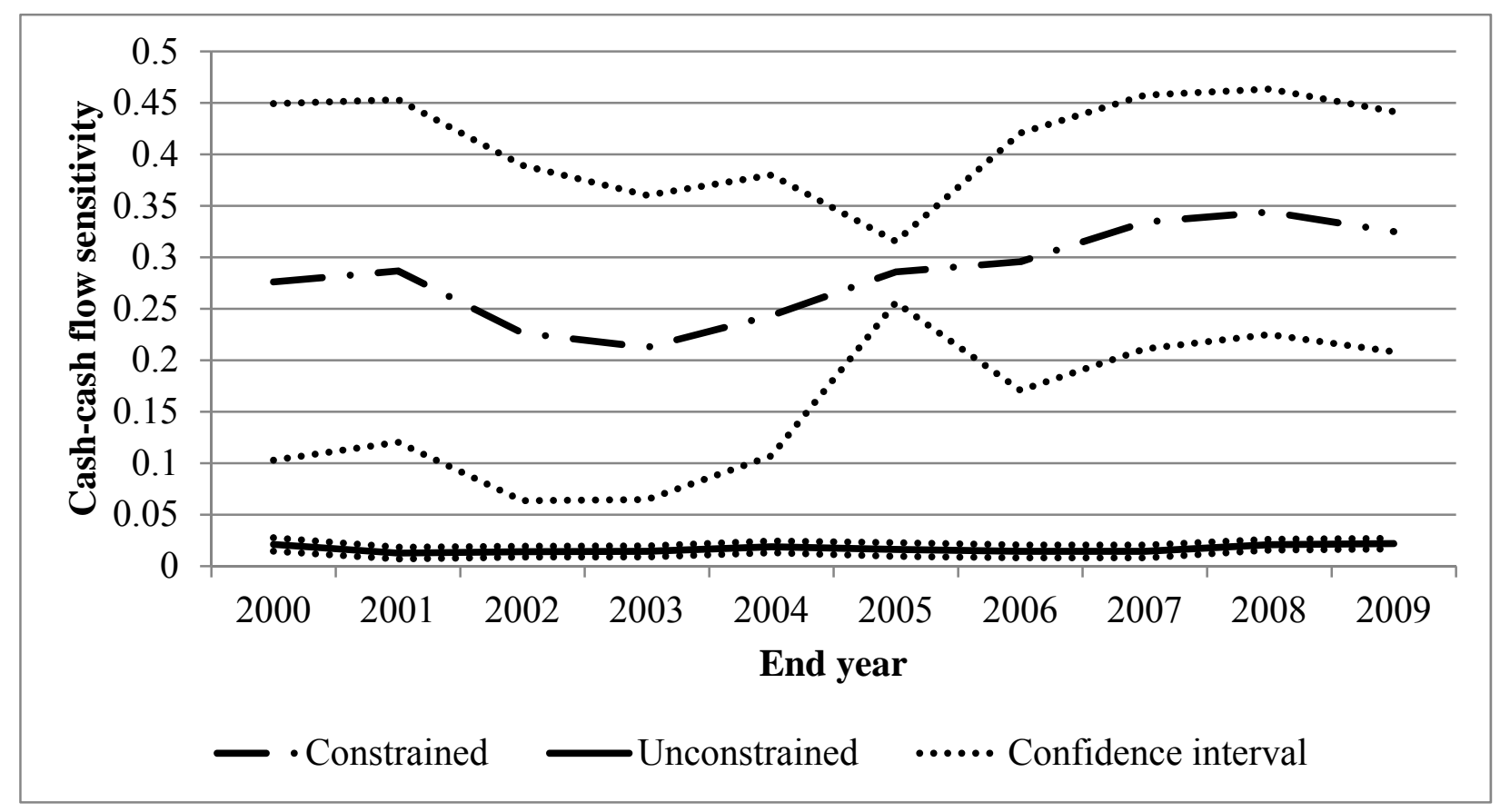

Figure 1. Stability of cash-cash flow sensitivity

Notes: In this we use the sample from the year 1993 to 2000 as the base and then add one year in subsequent steps to check the stability of CCFS. 


\subsection{Results of the Regime Switching Model using Listed Firms}

In our main result (Table 3), we have used accelerator to represent the growth opportunities of firms as we have many unlisted firms in the sample. For a sub-sample of firms that are listed, we present the results of the endogenous regime switching regression in Table 4 by introducing Tobin's $q$ to the basic specification. This makes our results more comparable to studies in the existing literature which use Tobin's $q$ to investigate finance constraints in firms.

As done above, we test the existence of two distinct cash holding regimes using $\chi 2$ tests suggested by Goldfeld and Quandt (1976). The test rejects the hypothesis of similar cash holding behavior by the two regimes at $0.1 \%$ significance level. In Panel B (Table 4), the coefficient of cash flows is significantly greater in the first regime. Therefore, we consider the first regime as financially constrained and the second regime as financially unconstrained.

In Panel B, the coefficients in both the regimes, except log sales, are consistent with the main results in Table 3. The coefficient associated with log sales, which was insignificant earlier, is now significant with a positive sign in the second regime. This suggests that firms with high operating income, in the second (unconstrained) regime are more probable to hold cash. This offers support to the economies of scale argument normally associated with the cash holdings. The estimates of the selection equation (Panel A) reveal that all the significant selection characteristics are consistent with the main results (Table 3 ).

The overall results suggest that, firms with higher operating income, long term debt, export sensitivity and; firms with group affiliation and positive industry sales shock are more likely to unconstrained. Also, firms with lower maturity, cash holding, tangibility and growth opportunities are more likely to be unconstrained. The coefficients of maturity and tangibility are contrary to our expectations. This is because the firms with more maturity and tangible assets are perceived to be more reputed and are likely to hold more collateralisable assets, respectively. However, these findings can be substantiated by existing research on the Indian firms which suggests that the Indian Government in its attempt to promote industrialisation, has favored small and young firms (Ganesh-Kumar, Sen and Vaidya, 2001; Bhaduri, 2005). 


\section{Macrothink}

Table 4. Endogenous regime switching regression (only listed firms)

Panel A. The selection equation

\begin{tabular}{lc}
\hline & Coefficients \\
\hline Log sales & $-0.0631^{* * *}$ \\
Log age & $(4.94)$ \\
& $0.1369^{* * *}$ \\
Dividend payout/K & $(5.97)$ \\
& -0.0655 \\
Cash holding/K & $(1.31)$ \\
Asset tangibility/K & $0.0330^{* * *}$ \\
Tobin's q & $(6.37)$ \\
Accelerator/K & $0.0084^{*}$ \\
Short term debt/K & $(2.01)$ \\
Long term debt/K & $0.2984^{* * *}$ \\
Export sensitivity & $(10.49)$ \\
Group affiliation & $0.0026^{* *}$ \\
Industry sale shock & $(2.65)$ \\
\hline Prob $>\mathrm{F}$ & -0.0070 \\
\hline & $(1.15)$ \\
& $-0.0073^{*}$ \\
& $(2.09)$ \\
& $-0.0411^{*}$ \\
& $(2.24)$ \\
& $-0.0694^{*}$ \\
& $(2.46)$ \\
& $-1.4297^{* * *}$ \\
& $(12.04)$ \\
\hline
\end{tabular}


Panel B. The cash holdings equation

\begin{tabular}{lccc}
\hline $\begin{array}{l}\text { Dependent variable: } \\
\Delta \text { cash/K }\end{array}$ & $\begin{array}{c}\text { Regime } 1 \\
\text { Coefficients }\end{array}$ & $\begin{array}{c}\text { Regime } 2 \\
\text { Coefficients }\end{array}$ & $\begin{array}{c}\text { p-value for difference in } \\
\text { coefficients }\end{array}$ \\
\hline L. $\Delta$ slack/K & $-0.5020^{* * *}$ & $-0.0278^{* * *}$ & 0.0000 \\
Cash flows/K & $(6.95)$ & $(60.16)$ & 0.0000 \\
& $0.3114^{*}$ & $0.0239^{* * *}$ & 0.0000 \\
Tobin's q & $(2.21)$ & $(11.73)$ & \\
& -0.5895 & 0.0049 & 0.0000 \\
Accelerator/K & $(1.13)$ & $(1.08)$ & 0.0000 \\
& -0.0008 & $0.0055^{* * *}$ & \\
Capital & $(0.32)$ & $(4.45)$ & 0.0000 \\
expenditure/K & 0.0212 & $-0.0728^{* * *}$ & \\
Log sales & $(1.22)$ & $(7.58)$ & 0.0000 \\
& 0.2484 & $0.0079^{* *}$ & \\
$\Delta \mathrm{STD} / \mathrm{K}$ & $(1.66)$ & $(2.62)$ & 0.0000 \\
& $0.0808^{*}$ & $0.1014 * * *$ & \\
\hline NCWK/K & $(1.99)$ & $(4.43)$ & \\
\hline Prob> F & -0.0321 & 0.0006 & $(0.44)$ \\
\hline
\end{tabular}

Notes: The variables are defined in the Appendix. The total number of observations is 1934 . The estimation is done after controlling for firm and year effects. $* * *, * *$ and $*$ denote level of significance at $0.1 \%, 1 \%$ and 5\%, respectively. Absolute t-statistics are in parentheses.

\section{Conclusion}

The paper attempts to contribute to the corporate finance literature by providing some evidence on the identification of financially constrained firms. We depart from the common trend in related literature by using CCFS rather than the ICFS as the metric to measure financing constraints faced by the firms. The major advantage of the CCFS metric is that it evades the decomposition of cash flows into real and financial parts, which is a major bottleneck in using ICFS.

We use an endogenous regime switching model to analyse the determinants of cash holdings by firms. This method allows firms to change regime endogenously over the sample period and does not require the sensitivity metric measuring finance constraint to increase monotonically with the sorting variables. We find that firms holding large amount of cash in the previous period are less likely to hold cash in the current period; cash flows and change in short term debt are important sources of cash holdings; firms make capital expenditure by running down their cash holdings; and only when firms are constrained by external funds they are likely to run down non cash working capital to hold cash. We also find that firms with higher operating income, long term debt, export sensitivity and; firms with group affiliation 
and positive industry sales shock are more likely to be financially unconstrained. Also, firms with smaller maturity, cash holdings, asset tangibility and growth opportunities are more likely to be financially unconstrained. Our robustness checks lend credence to our findings as we substantiate the results for a sub-sample of firms that are listed by conducting the entire empirical exercise using the Tobin's $q$. We also tested the sensitivity of our estimates by establishing their stability in various sub-samples. The overall results reaffirm the case of financial rigidities which is much talked about in a developing country context. Future industrial policies need to address this concern to effectively produce the desired results.

\section{References}

Almeida, H., Campello, M., \&Weisbach, M. (2004). The Cash Flow Sensitivity of Cash. Journal of Finance, 59, 1777-1804. http://dx.doi.org/10.1111/j.1540-6261.2004.00679.x

Almeida H., \& Campello, M. (2007). Financial Constraints, Asset Tangibility, and Corporate Investment. Review of Financial Studies, 20, 1429-1460. http://dx.doi.org/10.1093/rfs/hhm019

Alti, A. (2003). How Sensitive is Investment to Cash Flow when Financing is Frictionless? Journal of Finance, 58, 707-722. http://dx.doi.org/10.1111/1540-6261.00542

Bhaduri, S. (2005). Investment, Financial Constraints and Financial Liberalization: Some Stylized Facts from a Developing Economy, India. Journal of Asian Economics,16, 704-718. http://dx.doi.org/10.1016/j.asieco.2005.06.001

Bertrand, M., Mehta, P., \& Mullainathan, S. (2002). Ferreting Out Tunneling: An Application to Indian Business Groups. Quarterly Journal of Economics, 117, 121-148. http://dx.doi.org/10.1162/0033553027533994

D'Espallier, B., Vandemaele, S., \& Peeters, L. (2008). Investment-Cash Flow Sensitivities or Cash-Cash Flow Sensitivities? An Evaluative Framework for Measures of Financial Constraints. Journal of Business, Finance and Accounting, 35, 943-968. http://dx.doi.org/10.1111/j.1468-5957.2008.02101.x

Denis, D., \& Sibilkov, V. (2010). Financial Constraints, Investment, and the Value of Cash Holdings. Review of Financial Studies, 23, 247-269. http://dx.doi.org/10.1093/rfs/hhp031

Devereux, M., \& Schiantarelli, F. (1990). Investment, Financial Factors, and Cash Flow: Evidence from UK Panel Data. In R. Hubbard (Eds.), Asymmetric Information, Corporate Finance, and Investment. National Bureau of Economic Research. 279-306.

Fazzari, S., Hubbard, R., \& Petersen, B. (1988). Financing Constraints and Corporate Investment. Brookings Papers on Economic Activity, 1988, 141-195. http://dx.doi.org/10.2307/2534426

Ganesh-Kumar, A., Sen, K., \& Vaidya, R. (2001). Outward Orientation, Investment and Finance Constraints: A Study of Indian Firms. Journal of Development Studies, 37, 
133-149. http://dx.doi.org/10.1080/00220380412331322071

Gautam, V., \& Vaidya, R. (2013). Firm Investment, Finance Constraint and Voluntary Asset Sales: The Evidence from Indian Manufacturing Firms. Macroeconomics and Finance in Emerging Market Economies, 6, 114-130. http://dx.doi.org/10.1080/17520843.2012.725419

Gilchrist, S., \& Himmelberg, C. (1995). Evidence on the Role of Cash Flow for Investment. Journal of Monetary Economics, 36, 541-572. http://dx.doi.org/10.1016/0304-3932(95)01223-0

Ginglinger, E., \& Saddour, K. (2007). Cash holdings, Corporate Governance and Financial Constraints. Open access publications, urn: hdl: 123456789/2938, UniversitÃ ( Paris-Dauphine.

Goldfeld, S., \& Quandt, R. (1976). Techniques for Estimating Switching Regressions. In S. Goldfeld, \& R. Quandt (Eds.), Studies in Non-Linear Estimation, Cambridge: Ballinger Press.

Hoshi, T., Kashyap, A., \& Scharfstein, D. (1991). Corporate Structure, Liquidity, and Investment: Evidence from Japanese Industrial Groups. Quarterly Journal of Economics, 106, 33-60. http://dx.doi.org/10.2307/2937905

Hovakimian, G., \& Titman, S. (2006). Corporate Investment with Financial Constraint: Sensitivity of Investment to Funds from Voluntary Asset Sales. Journal of Money, Credit and Banking, 38, 357-374. http://dx.doi.org/10.1353/mcb.2006.0034

Hovakimian, G. (2009). Determinants of Investment Cash Flow Sensitivity. Financial Management, 38, 161-183. http://dx.doi.org/10.1111/j.1755-053X.2009.01032.x

Hu, X., \& Schiantarelli, F. (1998). Investment and Capital Market Imperfections: A Switching Regression Approach using US Firm Panel Data. Review of Economics and Statistics, 80, 466-479. http://dx.doi.org/10.1162/003465398557564

Hubbard, R. (1998). Capital Market Imperfections and Investment. Journal of Economic Literature, 36, 193-225.

Jensen, M., \& Meckling, W. (1976). Theory of the Firm: Managerial Behavior, Agency Costs, and Ownership Structure. Journal of financial economics, 3, 305-360. http://dx.doi.org/10.1016/0304-405X(76)90026-X

Jensen, M. (1986). Agency Costs of Free Cash Flow, Corporate Finance, and Takeovers. American Economic Review, 76, 323-329.

Jorgenson, D. (1963). Capital Theory and Investment Behavior. American Economic Review, $53,247-259$.

Kaplan, S., \& Zingales, L. (1997). Do Finance Constraints Explain Why Investment is Correlated with Cash Flow? Quarterly Journal of Economics, 112, 169-215. http://dx.doi.org/10.1162/003355397555163 
Khurana, I., Pereira, R., \& Martin, X. (2006). Financial Development and the Cash Flow Sensitivity of Cash. Journal of Financial and Quantitative Analysis, 41, 787-808. http://dx.doi.org/10.1017/S0022109000002647

Kruse, T. (2002). Asset Liquidity and the Determinants of Asset Sales by Poorly Performing Firms. Financial Management, 31, 107-129. http://dx.doi.org/10.2307/3666176

Lensink, R., Bo, H., \& Sterken, E. (2001). Investment, Capital Market Imperfections, and Uncertainty: Theory and Empirical Results. Cheltenham: Edward Elgar Publication.

Lin, Y. (2007). The Cash Flow Sensitivity of Cash: Evidence from Taiwan. Applied Financial Economics, 17, 1013-1024.http://dx.doi.org/10.1080/09603100600749329

Maddala, G. (1983). Limited-Dependent and Qualitative Variables in Econometrics. Cambridge: Cambridge University Press.

Myers, S., \& Majluf, N. (1984). Corporate Financing and Investment Decision When Firms Have Information That Investors Do Not Have. Journal of Financial Economics, 13, 187-221. http://dx.doi.org/10.1016/0304-405X(84)90023-0

Roland, C. (2008). Banking Sector Liberalization in India. Heildelberg: Pysica-Verlag Press.

Salinger, M., \& Summers, L. (1983). Tax Reform and Corporate Investment: A Microeconometric Simulation Study. In M. Feldstein (Eds.), Behavioral Simulation Methods in Tax Policy Analysis, 247-281. Chicago: University of Chicago Press.

Sen, K., \& Vaidya, R. (1997). The Process of Financial Liberalization in India. New Delhi: Oxford University Press.

Stiglitz, J., \& Weiss, A. (1981). Credit Rationing in Markets with Imperfect Information, American Economic Review, 71, 393-410. http://dx.doi.org/10.2307/1802787

Stulz, R. (1990). Managerial Discretion and Optimal Financing Policies. Journal of Financial Economics, 26, 3-27. http://dx.doi.org/10.1016/0304-405X(90)90011-N

Tobin, J. (1969). A General Equilibrium Approach to Monetary Theory. Journal of Money, Credit and Banking, 1, 15-29. http://dx.doi.org/10.2307/1991374

\section{Appendix. Variable Definitions:}

Accelerator: First difference of operating income (sales).

Asset tangibility: Stock of the gross fixed assets of a firm.

Cash holding: Sum of cash and marketable securities.

Cash flows:Sum of retained profits and depreciation.

Capital expenditure: Expenditure on investment. 
Distress: A firm is classified as distressed in a year if its profit before depreciation, interest, taxes and amortisation (PBDITA) is less than 80 percent of the interest accrued in the current year or PBDITA is less than the interest accrued in the current year and the year before.

Dividend payout: Sum of common and preference dividends.

Export sensitivity: Ratio of export of goods (fob) to sales.

Group affiliation: Dummy, which takes the value 1 for a firm belonging to group.

Industry sales shock: Sales growth in an industry, net of average sales growth across all industries over the past two years.

Interest coverage: Ratio of interest accrued to PBTIDA.

Long term debt: Loans taken from all sources for a period exceeding 12 months.

Maturity: Natural log of age where age is taken as the difference between year of incorporation of a firm to the current year.

Non-cash working capital: Current assets net of cash holdings.

Operating income/size: Natural log of sales.

Regime dummy: Dummy which takes the value 1 for the first regime.

Short term debt: Loans taken from all sources for a period of less than 12 months.

Tobin's q: The ratio of market value of a firm to its book value of assets. Market value is calculated by adding market value of equity and book value of debt.

\section{Notes}

Note 1. ICFS, as a measure of finance constraints faced by firms, was first suggested by Fazzari, Hubbard and Petersen (1988).

Note 2. Neoclassical theory, assuming perfect capital markets, suggests that the growth opportunities of firms should be the sole determinant of investment decisions (Jorgenson, 1963; Tobin, 1969). Therefore it must be controlled in an investment regression to identify financially constrained firms. See Hubbard (1998) and Lensink, Bo and Sterken (2001) for a comprehensive review of literature on the use of ICFS as a metric to measure financial constraints.

Note 3. In practice, firms are always financially constrained to a varying degree (Hubbard, 1998). Therefore, the group of firms having higher CCFS is more financially constrained than the group of firms having smaller CCFS.

Note 4. For a comprehensive review of the reforms seeSenand Vaidya (1997) and Roland (2008).For a review of literature on finance constraints in Indian firms see Gautam and Vaidya (2013). They analyse finance constraints in Indian firms using investment-asset sales sensitivity. We consider a comparative assessment of their work with the current work for 
future research.

Note 5. The KZ index is derived from the results in Kaplan and Zingales (1997). It is the weighted sum of cash flows, Tobin's $q$, leverage, dividends and slack. The Tobin's $q$ and leverage are given positive weight and the other three variables are given negative weight. This index, by design, has higher values for unconstrained firms.

Note 6. Their financial development index is an average of five standardised indices: market capitalisation over the GDP, total value traded over the GDP, total value traded over market capitalisation, the ratio of liquid liabilities to the GDP, and the credit going to the private sector over the GDP.

Note 7. We use 'perpetual inventory method' to construct replacement value of capital stock. This is a standard practice in the literature. See Salinger and Summers (1983) for a comprehensive note.

Note 8. We allow up to a ten-fold jump if the manufactured sales is up to Rs. (Indian Rupees) 10 million; five-fold if the manufactured sales is between Rs. 10 million to Rs. 50 million; four-fold if the manufactured sales is between Rs. 50 million to Rs. 100 million; three-fold if the manufactured sales is between Rs. 100 million to Rs. 250 million; and two-fold if the manufactured sales is above Rs. 250 million. We tried various other cutoffs but these cutoffs are chosen to include maximum possible number of observations in the sample and putting a restriction on the restructuring firms.

Note 9. Definitions of the variables are in the Appendix.

Note 10. Our specification is slightly different from the model in Almeida, Campello and Weisbach (2004). They use the Tobin's $q$ to represent growth opportunities of firms. We use accelerator because our sample includes unlisted firms as well. Further, they use acquisitions, which we are unable to use because of lack of data on acquisitions for a large proportion of firms. Moreover, they do not use $\Delta \operatorname{Cash}_{i, t-1}$ but we use it to control for the previous period's change in cash holding

Note 11. We do not interpret the coefficients here. Our main estimation results are presented in the next Section.

Note 12. For a comprehensive note on the model see Maddala (1983).

Note 13. The second equality in equation (13) uses the fact that a joint density equals the product of conditional density and the marginal density. If $\beta_{1}$ is equal to $\beta_{2}$ and $\sigma_{1 \varepsilon}$ is equal to $\sigma_{2 \varepsilon}$ then $u_{1}$ is equal to $u_{2}$ and the likelihood function reduces to a standard normal density.

\section{Copyright Disclaimer}

Copyright reserved by the author(s).

This article is an open-access article distributed under the terms and conditions of the CreativeCommons Attribution license (http://creativecommons.org/licenses/by/3.0/). 